\title{
First-Time Voter Education Through the Democracy Volunteer Movement
}

\author{
Suryanef 1, Al Rafni \\ Pancasila and Civic Education Department, Faculty of Social Sciences, Universitas Negeri Padang, \\ Indonesia \\ ${ }^{1}$ suryanef@fis.unp.ac.id
}

\begin{abstract}
Ahead of the 2014 election, the General Election Commission (KPU) established a group of facilitators to educate the public about the election (voter education), called Democracy Volunteers (Relawan Demokrasi), in cities/regencies throughout Indonesia. Democracy Volunteers is a program aimed at increasing political participation and election quality. One of the target groups for the voter education is first-time voters. First-time voters are perceived to have distinctive political behavior; their political actions are qualitatively different from other segments of voters. They are also classified as the technology savoy generation. This paper intends to elaborate the Democracy Volunteers' efforts in implementing voter education for first-time voters, and reveal the most suitable voter education model for this segment of voters. The research used qualitative method through focus group discussions and in-depth interviews. The results show that a voter education model for first-time voters is needed in order that Democracy Volunteers carry out the voter education effectively in achieving the expected goals.
\end{abstract}

Keywords: Democracy Volunteer, Relawan Demokrasi, voter education, first-time voters

\begin{abstract}
ABSTRAK
Menjelang pemilu 2014, Komisi Pemilihan Umum membentuk Relawan Demokrasi sebagai fasilitator pendidikan pemilih (voter education) di kabupaten/kota seluruh Indonesia. Relawan Demokrasi merupakan sebuah gerakan untuk meningkatkan partisipasi politik dan kualitas pemilu. Salah satu khalayak sasaran yang menjadi target edukasi dari Relawan Demokrasi adalah pemilih pemula. Pemilih pemula diasumsikan memiliki perilaku politik yang khas dan tindakan politik yang secara kualitatif berbeda dengan segmen pemilih lainnya. Di samping itu, mereka juga tergolong ke dalam generasi yang melek teknologi. Tulisan ini hendak mengelaborasi upaya relawan demokrasi dalam melaksanakan pendidikan pemilih bagi pemilih pemula, dan bagaimana model pendidikan pemilih yang tepat untuk segmen pemilih ini. Metode penelitian yang digunakan adalah kualitatif melalui focus group discussion (FGD) dan in-depth interview. Hasil penelitian menunjukkan perlunya model pendidikan pemilih bagi pemilih pemula yang akan diimplementasikan oleh relawan demokrasi dalam melaksanakan tugasnya agar pendidikan pemilih yang dilakukannya berjalan efektif dalam mencapai tujuan yang diharapkan.
\end{abstract}

Kata Kunci: Relawan Demokrasi; pendidikan pemilih; pemilih pemula

This work is licensed under the Creative Commons Attribution-ShareAlike 4.0 International License. (C2020 by the author(s).

Received: August $72020 \quad$ Revised: November 52020

Accepted: November 112020

\section{INTRODUCTION}

Consisting of members from the community, Democracy Volunteers group 
was established as a partner of the General Elections Commission (KPU) to implement voter education for certain community groups such as women group, religious groups, marginalized groups, the disabled, and first-time voters. These groups are believed to get less than optimal socialization from KPU, while they potentially own large enough number of votes to lead certain candidates or political parties to victory. The first-time voters, based on the data released by KPU in the 2009 legislative elections, amount to $20-30 \%$ of 186.612 .255 listed Indonesian voters (Komisi Pemilihan Umum, 2009). In the 2014 election, the number increased significantly to between $40-42 \%$.

The first-time voters, in terms of political economy and if associated with the demographic bonus of Indonesia, according to a report by Mc Kinsey Institute, will make Indonesia one of the seven countries with the world's largest economic growth by 2030, passing Germany and the United Kingdom. An estimated $70 \%$ of the Indonesian population is in the productive age group of 15-64 years old and it is predicted to last for the next 18 years (Mc Kinsey, 2012).

Research on this issue have been mostly conducted in various types. Firsttime voters' political behavior in learning about democracy life is revealed in Yoldaş (2015). According to his research, political socialization and individual experience, particularly of the young generations, are prominently complex processes by which democracy becomes a jargon and only attracts very little concern. Therefore, it is highly necessary to improve political/civic education in order to strengthen the participation as a basic principle of democracy. Another research by Astuti (2016) disclosed that the diffusion of political information through television and social media is very influential to increase political participation for first-time voters. Research on first-time voters' political behavior is also revealed by Mac and Ghail (2010) in their paper titled "Educating for Political Activity: A younger generational response". It mentions that different socio-cultural reality can be used as a guide for the political sensitivity of the youths. From the illustration above, it can be seen and understood that first-time voters are community members that need continuous education and are expected to be intelligent and rational voters.

The formation of a person's rationality in voting process is mainly determined by the voting behavior. According to Anthony Downs, there are two groups of voters based on the characteristics of voting behavior: rational voters and traditional voters. The first group uses voting rights on the rationality basis or their own will without being influenced by other people. The second group uses their voting rights not based on rationality or personal will, but rather at the instigation of others such as elder relatives, public figures, as well as the government (Suryanef \& Rafni, 2016).

Rational voters, therefore, show these five characteristics: (1) able to take decisions when faced with alternatives; (2) able to compare whether a choice is preferred, in the same or lower level compared to other alternatives; (3) able to draft alternative choices: if $\mathrm{A}$ is more preferred than $\mathrm{B}$, and better than $\mathrm{C}$, then $\mathrm{A}$ is more preferred than $C$; (4) able to choose alternatives with higher preference levels; and (5) always take the same decision when faced with the same alternatives (Efriza, 2012). 
Rational choice theory requires options to be ranked by the individual. Ranks of options are based on the individual's knowledge such as the benefits and cost of the choices made. According to Florina as quoted by Asrinaldi (2012), rational voters will associate their actions with past events (retrospective). Such process requires the individuals to evaluate information related to parties, candidates, and policies. The more information obtained, the better the results of the evaluation. This evaluation is intended as a basis for learning and action in prior so that voters do not suffer losses in the future (Suryanef \& Rafni, 2016).

In order to be rational voters, first-time voters need to be provided with political education, hence the Democracy Volunteer movement. In this respect, this voluntary program is a strategic attempt to expand political participation in the community while enhancing public trust towards the democratic process.

Several other studies also reveal the importance of voter education for firsttime voters. In fact, some developed countries consider this a serious problem that must be the concern of all political systems. Campbell and Niemi (2016) as well as Persson, Lindgren and Orkarsson (2016) reveal that in educating first-time voters, voter education is carried out with the availability of the following tools: (1) standard operating procedures; (2) learning design; (3) collaboration or networking; (4) sustainable evaluation system; (5) government commitment; and (6) suitable materials and methods in accordance with the characteristics of first-time voters (Campbell \& Niemi, 2016; Persson et al., 2016). Heller (2013) also researched on a program called the "U-18 Program" in Germany. This program is a political education aimed at adolescents using a simulation method in order to attract their interest in politics, particularly in elections (Heller, 2013).

In Indonesia, voter education has also been implemented, although previously the patterns tended to be doctrinal, formalistic, and top-down, conducted by actors and facilitators from the bureaucratic or government officials. This has not achieved the results expected. In this regard, the General Election Commission (KPU) seeks to improve the implementation of voter education by establishing Democracy Volunteers program based on Circular Letter No. 609/KPU/IX/2013. This program was started in preparing for the 2014 election. The regulation was then updated through the Technical Guidelines for the Implementation of the Democracy Volunteers Program Number 32/PP.08-SD/06/KPU/I/2019 dated 9 February 2019. This program is also intended as an effort to involve community participation as a pioneer of democracy for the community in organizing elections.

Democracy Volunteers is a breakthrough civil society movement because it is different from previous voter education programs where the facilitators or educators come from the government or outside of the targeted community. Democracy Volunteers facilitators, who are also community members, are expected to bring significant changes in implementing political/voter education because previously the process of cultivating political values has been strongly influenced by the interests of the authorities, is indoctrinated, formalistic, and benefits only certain groups. Therefore, it can be stated that Democracy Volunteers are facilitators of political education for their own communities. Through the Democracy Volunteers, 
political education is expected to function in a sustainable, systemic, and programmatic manner (Suryanef \& Fatmariza, 2014).

Therefore, this article aims to elaborate Democracy Volunteers' efforts in conducting voter education for first-time voters, as well as reveal the most suitable voter education model for the voters.

\section{RESEARCH METHOD}

This paper is part of the author's research titled "Development of a Training Model for Democracy Volunteers as Facilitators of Community-Based Political Education". The method used in general is Research and Development (R\&D). However, the findings are described in this article qualitatively, namely an approach where the findings are not obtained through statistical procedures or other forms of calculation but emphasized on interpretative studies. (Strauss \& Corbin, 2003). Research informants were determined purposively, including Democracy Volunteers members and Padang City KPU commissioners, as well as first-time voters who were the target of political education and were selected randomly. Data were collected through in-depth interviews, focus group discussions (FGD), and documentation studies. Data analysis was carried out using qualitative data analysis steps starting with data collection, data reduction, data presentation, and drawing conclusions. The validity of the data was obtained through credibility, transferability, dependability, and confirmability (Denzin \& Lincoln, 2006).

\section{RESULTS AND DISCUSSION}

This section elaborates research findings and discussion about (1) the Democracy Volunteers' efforts in conducting voter education for first-time voters; and (2) voter education model for first-time voters.

The idea to establish Democracy Volunteers program derived from the fact that voters' turnout tended to decrease both in quantity and quality. The last three national elections before 2019 and the local elections in various regions showed such indication. In the 1999 national elections, the voters' turnout was 92\%, in the 2004 election it became $84 \%$, in 2009 it was $71 \%$, and in 2014 it was only $53.6 \%$. The same phenomenon also occurred at the regional level. In West Sumatera, for example in Padang city, voters' participation in the 2004 legislative elections was up to $70 \%$, in the presidential elections it decreased to almost $64 \%$, even the voters' participation in the West Sumatra 2005 gubernatorial election was only 52\%, while legislative election of 2014 was up to $56.3 \%$. In terms of quality, people tend to keep a pragmatic pattern in voting. Therefore, the momentum of Democracy Volunteers program is believed to be able to provide a significant contribution in conducting political education for the community, and in turn, to improve voters' participation as well as the quality of democracy.

The Democracy Volunteer program served in January 2014 during the process of local election in Padang. It consisted of 25 people, who were divided into groups of targeted voters; eight people for first-time voters' group, four people for women's group, five people for marginal voters, five people for religious group, and three people for disabled group. For the first-time voters' group, the efforts conducted by 
the Democracy Volunteers were as follows:

First, as their basic task, Democracy Volunteers mapped each region according to residences and surroundings. The task is considerably important to organize the dissemination among the 11 districts of Padang city. The findings showed that the political socialization and education process has not spread evenly due to the limitation in funding and resources. For three months, the volunteers could only conduct nine events to disseminate political education for voters. From all events, only 185 first-time voters could be reached by volunteers. Therefore, it can be concluded that the Democracy Volunteers achievement in three-month implementation of voter education was quite low.

Second, Democracy Volunteers identified the materials and methods of dissemination that would be given to first-time voters. The materials were prepared by considering the unique characteristics of first-time voters. Therefore, the voter education materials for first-time voters were aimed to enhance their capacity to change and shape political behavior in order to become responsible participants. With the continuous efforts, it will create public order suitable with the nature of voter education. Concerning the matter, Democracy Volunteers designed the proper materials and methods and then disseminated them to first-time voters. The materials given were as follows: (1) the importance of democracy, elections, and participation; (2) the procedures of granting votes in elections; and (3) introduction to the electoral contestants. In presenting such materials, the methods used by volunteers are as follows: (1) simulation; (2) lectures; (3) roleplay; (4) Focus Group Discussion (FGD); and (5) posting the dissemination topics to the social media. For the success of subject delivery, visual and nonvisual tools were also employed.

Third, democratic volunteers reached local governments and high school, as well as colleges in Padang. This access was intended to generate integrity in achieving the target of voter education to become rational voters. Such synergy can be drawn in the form of the development of learning materials and methods under the implementation of the voter education.

When examined further, it can be inferred that the efforts made by Democracy Volunteers in educating first-time voters about political and democratic life, especially regarding the elections, is a breakthrough and innovation in the implementation of voter education. The presence of Democracy Volunteers changes the paradigm of political education in terms of sources, materials presented, and the methods used, which were tailored to the interests of the community and was proximate to the conditions and situations of the community. This factual condition can be classified as a form of transformative political education. Transformative political education is the political education that "builds in" from the existing awareness in society, facilitated by the community itself as an agent of political change. The materials and strategies, as well as the educational media are selected according to the characteristics of the target audience (Suryanef \& Fatmariza, 2014).

Furthermore, when viewed from a learning perspective, the voter education conducted by Democracy Volunteers for first-time voters can also be called a form of transformative learning. Voter education by democratic volunteers is oriented 
towards changing ways of thinking that not only involve cognitive and rational aspects, but also emotional aspects. This condition is intended as an effort to shape critical thinking, as well as to determine the right attitude and quickly make the right decisions (Sirimorok, 2010).

By accommodating transformative learning, voter education as part of political education is no longer just an effort to add information and knowledge, but at the same time becomes an effort to shape attitudes and skills as intelligent, critical, and autonomous citizens. Based on this, throughout his life humans continue to learn to live in harmony, together in a social bond from the little ones to the nationwide bonds. All of this is done so that humans can understand their status as good citizens living together in the community, including in the relationship between nations.

The need to increase the number of potential voters as well as to improve political participation requires the planning of programmed voter education. Proper attention must be paid to the planning of programs, consistent implementation, and result monitoring of voter education activities. There are three valuable things to consider in reaching the better voter education model in future.

First, Democracy Volunteers must determine the voter education strategy that can be implemented, including comprehensive and measurable design of voter education management for first-time voters. The similar concern has been expressed by (Campbell \& Niemi, 2016), who have conducted a research on citizens aged 18-24 years old during 2006-2010 to find out the level of youth's political knowledge through the National Assessment of Educational Progress (NAEP). This study reveals that it is necessary to conduct evaluation throughout the process of voter education. Similar studies were also conducted by Persson et al (2016) on 30.000 students to examine the influence of educational level towards political knowledge, participation, and democratic values. From these studies, it can be concluded that in the developed countries, there has been (1) the determination of policymakers and political scientists to create measures for the successful implementation of voter or political education; (2) proper learning devices; (3) supervision by the regional government on voter education process; (4) networks of cooperation from various parties; (5) concerns on the special needs of beginner voters; and (6) systems of ongoing evaluation.

Second, Democracy Volunteers should be able to choose the suitable materials for the first-time voters. The materials considered to be appropriate for voter education are about: (1) the rights and responsibilities of citizens; (2) the functions of election in a democratic nation; (3) the electoral system and regime; (4) the characteristics of smart voters; (5) the organizers of election; (6) the supervision of election; and (7) the electoral violations.

Third, Democracy Volunteers should be able to determine the proper method of voter education, including: (1) workshop; (2) lectures/dissemination; (3) focus group discussion (FGD); (4) simulation; (5) tours to observe democratic practices, called Democratic Touring; (6) roleplay; (7) peer group; (8) watching movies; (9) arts/traditional media; and (10) BRIDGE method. 
The findings on voter education model can be further illustrated in the following diagram:

\section{Figure 1. First-Time Voter Education Model by Democracy Volunteers}

\section{Voter Education Strategy:}

A comprehensive voter education pattern

$>$ Proper learning devices for the election course

$>\mathrm{SOP}$ of voter education

$>$ Supervision from local government on the process of voter education

$>$ Cooperation network with various parties

$>$ Access for all beginner voters

$>$ Ongoing evaluation system

$>$ Concerns on the special needs of beginner voters

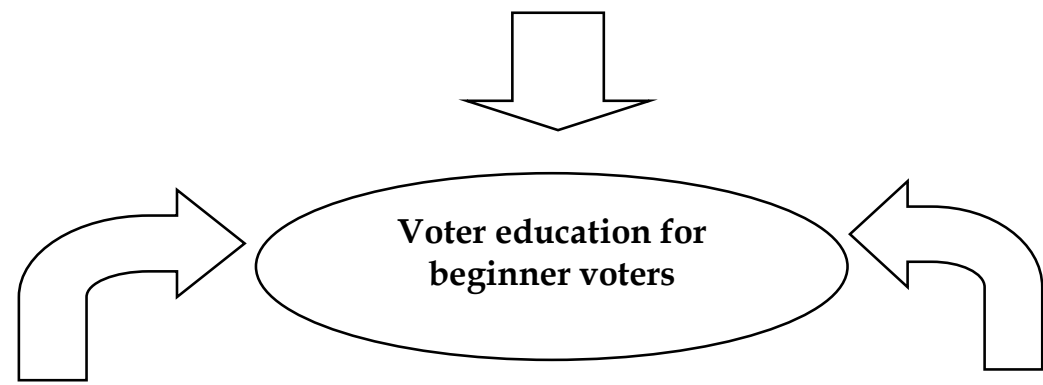

\begin{tabular}{|ll|}
\hline & Voter education materials: \\
$>$ & Citizens' rights and \\
& responsibilities \\
$>$ & Election functions in democratic \\
& nation \\
$>$ & Electoral system and regime \\
$>$ & Becoming smart voters \\
$>$ & Election organizers \\
$>$ & Election supervision violations \\
\hline
\end{tabular}

Voter education method:

$>$ Workshop

$>$ Lectures/dissemination

$>$ Focus group discussion (FGD)

$>$ Simulation

$>$ Democratic Touring

$>$ Roleplay

$>$ Peer group

$>$ Movie sessions

$>$ Arts/traditional media

BRIDGE method

Voter education is the process of delivering information to voters to increase their knowledge, understanding, and awareness about the election. As an effort to educate, voter education should be systematic and comprehensive in empowering voters. Therefore, voter education aims not only to what people describe as making learners implement their voting rights correctly and understand the election mechanism. Voter education aims much further than just that premise. It must be planned in detail, systematic and programmed with the beneficial choices of materials, either for short-term or medium-term.

Essentially, the elements within voter education are the continuous activities for self-education. Education will proceed; thus, every learner is expected to understand themselves and the situation of their surroundings. Moreover, it will enable them to value everything critically, which will further determine the behavior 
and ways for overcoming obstacles in their life. Such education is particularly apart from the formal education, where there is an introduction of understanding, the ways to have critical thinking, to decide and change behavior, and to design the real action (change, create, repair, complete; active actions). Through such education, people will attempt to figure out their surrounding's socio-political problems, then discuss, get involved to think, participate, and overcome the problems using alternative ways with unemotional and insistent behavior that will lead to problem solving through active actions with the clear direction and objectives.

\section{CONCLUSION}

The reseachers would simply like to draw the attention once more to the fact that voter education for first-time voters through the Democracy Volunteers movement was developed through proper model guidelines. In terms of materials, strategies, and methods, they apply selective policy based on the characteristics of political behavior mostly demonstrated by the majority of first-time voters. This article elaborates the findings of research that proper voter education materials, strategies, and methods by the volunteers become the considerable determining factors for the success of such voter education.

\section{REFERENSI}

Asrinaldi. (2012). Politik Masyarakat Miskin Kota. Gaya Media.

Astuti, P. A. A. (2016). Broadcast Political Information Through Social Media and Efforts to Increase the Political Participation of Young Voters. Asian Journal of Multidisciplinary Studies, 4(9), 1-11. http://www.ajms.co.in/sites/ajms2015/index.php/ajms/article/view/2008

Campbell, D. E., \& Niemi, R. G. (2016). Testing civics: State-level civic education requirements and political knowledge. American Political Science Review. https:// doi.org/10.1017/S0003055416000368

Denzin, N. K., \& Lincoln, Y. S. (2006). The Sage Handbook of Qualitative Research, 2nd ed. Edited by Norman K. Denzin, and Yvonna S. Lincoln. Library.

Efriza. (2012). Political Explore: Sebuah Kajian Ilmu Politik. Alfabeta.

Heller, L. (2013). Pendidikan Politik Lewat Pemilu Untuk Remaja. https:// www.dw.com/id/pendidikan-politik-lewat-pemilu-untuk-remaja/a17091532

Komisi Pemilihan Umum. (2009). Buku Saku Pemilu 2009: Hasil Pemilu Anggota DPR, $D P D$, dan DPRD. Jakarta.

Mac \& Ghaill, M. (2010). Educating for political activity: A younger generational response. Educational Review. https:// doi.org/10.1080/00131911.2010.516819

Mc Kinsey. (2012). The Archipelago Economy: Unleashing Indonesia's Potentials. In Global Intitute Report.

Persson, M., Lindgren, K. O., \& Oskarsson, S. (2016). How does education affect adolescents' political development? Economics of Education Review. https:/ / doi.org/10.1016/j.econedurev.2016.03.015

Sirimorok, N. (2010). Membangun Kesadaran Kritis: Kisah Pembelajaran Partisipatif Orang Muda. Insist Press. 
68 | Suryanef, Al Rafni

First-Time Voter Education...

Strauss, A., \& Corbin, J. (2003). Dasar-dasar penelitian kualitatif : tatalangkah dan teknik-teknik teoritisasi data. In Pengolahan Air Limbah Domestik Individual Atau Semi Komunal.

Suryanef, \& al Rafni. (2016). Relawan Demokrasi dan Upaya Pembentukan Rasionalitas Pemilih Pemula dalam Pemilu 2014 di Kota Padang.

Suryanef, \& Fatmariza. (2014). Pengembangan Model Pendidikan Pemilih (Voter's Education) Dalam Rangka Membangun Rasionalisasi Perilaku Memilih Pemilih Pemula dalam Pemilu di Kota Padang.

Yoldaş, Ö. B. (2015). Civic Education and Learning Democracy: Their Importance for Political Participation of Young People. Procedia - Social and Behavioral Sciences. https:// doi.org/10.1016/j.sbspro.2015.01.703 